\title{
Seasonal variation in hyperiid amphipod abundance and diversity and influence of mesoscale structures off Baja California
}

\author{
Bertha E. Lavaniegos ${ }^{1, *}$, Clara M. Hereu ${ }^{1,2}$ \\ ${ }^{1}$ Departamento de Oceanografía Biológica, CICESE, Km 107 Carretera Tijuana-Ensenada, Apdo, Postal 360, CP 22860, \\ Ensenada, Baja California, México \\ ${ }^{2}$ El Colegio de la Frontera Sur, Unidad Chetumal, Apdo, Postal 424, C.P. 77000, Chetumal, Quintana Roo, México
}

\begin{abstract}
Hyperiid amphipods collected during 4 IMECOCAL (Spanish acronym for Mexican Investigations of the California Current) cruises in January, April, July, and October 2005 were analyzed for seasonal variation in abundance and diversity and to determine the influence of surface circulation. The number of species was high in all seasons (between 79 and 92), but abundances showed remarkable differences. The total number of amphipods was lowest in January and highest in October (geometric means were 82 and 606 ind. $1000 \mathrm{~m}^{-3}$ respectively). Multivariate analysis based on similarity indices demonstrated a tight coupling between species composition and mesoscale structures. The largest cluster joined 67 stations, with $40 \%$ of similarity being explained by 4 species (Vibilia armata, Lestrigonus schizogeneios, Eupronoe minuta, and Primno brevidens). The geographic position of these stations coincided with the main California Current (CC) flow from spring to autumn. Subgroups were defined by minor seasonal differences. In contrast, the $\mathrm{CC}$ flow during winter was reduced to a meander off north Baja California, and was surrounded by oligotrophic water as indicated by the presence of the hyperiids Anchylomera blossevillei and Phrosina semilunata plus 3 of the dominant species ( $V$. armata, E. minuta, and P. brevidens). To the south of this front, other clusters with high oceanic influence were formed. In 2005, 3 eddies were detected in the area: one anticyclonic eddy in April and 2 cyclonic eddies in July. The anticyclonic eddy located in the southwest had its own faunal cluster that had high diversity but low population density. The main species in the anticyclonic eddy was Platyscelus ovoides. Only one of the cyclonic eddies had a unique faunal identity, being strongly dominated by Vibilia armata; this was located in the north between the CC flow and the coast. The other eddy was large and situated in the middle of the area, with a faunal array analogous to that in the CC flow. Correlation between hyperiid and salp species abundances suggested that the increase in salps (Salpa fusiformis, Thalia orientalis, Cyclosalpa bakeri) in spring could be relevant, as many hyperiid species showed a strong increase at this time. However, the most correlated salp was Cyclosalpa danae, which occurred only in October. Chains of $C$. danae aggregates were firmly attached in the samples. This would promote the aggregation and survival of amphipod hosts, particularly small species such as Lestrigonus schizogenios and L. bengalensis.
\end{abstract}

KEY WORDS: California Current $\cdot$ Eddies $\cdot$ Crustaceans $\cdot$ Vibilia armata $\cdot$ Primno brevidens $\cdot$ Salps Resale or republication not permitted without written consent of the publisher

\section{INTRODUCTION}

Hyperiid amphipods are a group of peracarid crustaceans that are adapted to the pelagic environment. They are less abundant than copepods, although some species such as Primno brevidens and Vibilia armata may reach the same abundance as some euphausiid species (Lavaniegos \& Ohman 2003). Amphipod aggregations in high latitudes are important food for birds (Ogi et al. 1985) and seals (Dehn et al. 2007). In the subarctic, Themisto pacifica is a substantial food for squids (Uchikawa et al. 2004) and fishes (Kosenok 
et al. 2006), while in the northern sector of the California Current (CC), the species has been found in stomachs of salmon (Schabetsberger et al. 2003), mackerels (Brodeur et al. 1987) and myctophids (Suntsov \& Brodeur 2008).

The known association between amphipods and gelatinous zooplankton (Gasca et al. 2007) contributes to the aggregation of the former around gelatinous outbreaks such as salp swarms, favoring their ingestion by fishes (Schabetsberger et al. 2003). This mechanism can also play a relevant role in subtropical and tropical regions, where salp swarms frequently occur (Hereu et al. 2006, in press). For example, Phronima sedentaria use gelatinous material from salps to make a protective cover, and have been found abundantly in stomachs of bluefin tuna Thunnus maccoyii (Young et al. 1997), yellowfin tuna T. albacares (Repelin 1978) and the subtropical fish Brama japonica (Watanabe et al. 2003).

The high diversity of hyperiids has been exploited as an indicator of hydrographic features and climatic effects. Cluster analysis of amphipods provided evidence of the bifurcation of the central north Pacific gyre (Shulenberger 1982). Hyperiid amphipods have also been used as temporal indicators, typifying longterm changes in the CC (Lavaniegos \& Ohman 1999). Despite the trophic role of hyperiids in oceanic regions and their potential as indicators of circulation, there are no studies addressing the relationship between hyperiid diversity and hydrographic features in the CC. In the southwest Pacific, species composition has been investigated in warm-core eddies from the Coral Sea, as has the role of these eddies in the transportation of tropical hyperiids into the Tasman Sea (Young \& Anderson 1987). Bradford \& Chapman (1988) studied another warm-core eddy generated east of New Zealand, which aggregated diverse zooplankton species. In this eddy, a higher biomass was found in the center and species dominance was different from that in the community outside the eddy. Cold-core eddies have also been studied. In the Gulf of Mexico, coldcore eddies are formed by the Loop Current and carry a high abundance of amphipods with different species composition compared to waters outside the eddy (Gasca 2003). Gasca (2004) also compared cyclonic and anticyclonic eddies during summer, and found higher abundance of amphipods in cyclonic structures.

Eddy formation in the $\mathrm{CC}$ is very active (SotoMardones et al. 2004, Barth et al. 2005) and appears to play an important role in fish recruitment (Logerwell et al. 2001). Therefore, the present study investigated the relation between hyperiid species composition and abundance and mesoscale structures in the southern region of the CC. Studies on the seasonal variation of amphipods in the $\mathrm{CC}$ are lacking, and the present study shows seasonal contrasts of data from 4 quarterly cruises off Baja California.

\section{MATERIALS AND METHODS}

Cruises. Data and biological materials were collected during 4 cruises in the Mexican sector of the $\mathrm{CC}$, along the north and central portion of the Baja California peninsula (see Fig. 1). The cruises were conducted during the winter (January 21-February 10), spring (April 14-May 5), summer (July 14-August 4), and fall (October 13-27) of 2005 on the RV 'Francisco de Ulloa' by the IMECOCAL program (Spanish acronym for Mexican Investigations of the California Current). The cruises are hereafter referred to as 0501, 0504, 0507, and 0510, respectively. CTD casts were performed at all stations down to $1000 \mathrm{~m}$ depth. Double oblique zooplankton tows were performed with a bongo net $(71 \mathrm{~cm}$ diameter, $500 \mu \mathrm{m}$ mesh width) in the upper $200 \mathrm{~m}$. The volume of water strained was measured with a flow meter placed at the mouth of the net. Samples were preserved with $4 \%$ formalin and sodium borate.

Taxonomic analysis. Amphipods were counted and identified in the samples collected during nighttime $(\mathrm{N}=173)$ to guarantee better representation of vertically migrating species. Hyperiid species were identified in the complete sample based on Vinogradov et al. (1996). Salps were also counted and identified to species in selected nighttime stations $(\mathrm{N}=115)$ using the taxonomic keys of van Soest (1972) and Godeaux (1998). Abundance was standardized to ind. $1000 \mathrm{~m}^{-3}$.

Data analysis. Three types of analyses were performed. First, abundances during different seasons were compared using ANOVA; this was done for 66 species which were present in at least $10 \%$ of the samples in at least 1 cruise, with data being log transformed $\left(\log _{10} x+1\right)$ prior to analyses. Species with significant results $(\alpha=0.05)$ were subjected to Tukey's a posteriori contrast test to define the specific seasonal change.

Multivariate analyses were performed to resolve spatial structure. A data matrix of $66 \times 170$ resulted after the exclusion of 3 stations without amphipods. Bray-Curtis similarity indices between stations were calculated (applying the logarithmic transformation) for cluster analysis following the average group criterion. This analysis was intended to probe the hypothesis that stations would combine as a function of mesoscale structures. Nonmetric multidimensional scaling (NMS) ordination was also used to corroborate the clusters defined in the dendrogram (Clarke \& Gorley 2006). The diversity in the clusters was examined using rarefaction curves (Hurlbert 1971) by taking the accumulated number of individuals of the samples in the cluster but including all the species. Spearman correla- 
tion analysis was used to explore a possible relation between amphipods and salp species.

Additional data on total amphipods and salps as well as other gelatinous taxa (doliolids, siphonophores, medusae, and ctenophores) from cruises between 1998 and 2004 were used to estimate abundance anomalies in 2005. The zooplankton abundance data are available online (http://imecocal.cicese.mx/texto/prod/itzoop.htm). Anomalies were estimated by removing seasonal means on log transformed data.

\section{RESULTS}

\section{Environmental conditions}

The seasonal characteristics in 2005 were typical for the CC. January and April showed the lowest surface temperatures in the oceanic area, but intense cooling occurred along the coast in April and July due to coastal upwellings (Fig. 1). October was the warmest month but upwelling was still evident along the northern coast. The area south of Punta Baja invariably showed temperatures that were between 1 and $2{ }^{\circ} \mathrm{C}$ higher than those in the north.

Surface salinity was generally low, ranging between 33.1 and 34.1. This is part of a multiyear event of low salinity since 2002 (Gaxiola-Castro et al. 2008, Lavaniegos in press). The presence of equatorial water in 2005 was associated with the highest surface temperatures $\left(>18^{\circ} \mathrm{C}\right)$ and salinities $(>33.5)$. The saline wedge was more extended in January. In July, the equatorial water was located in the 2 most offshore stations in the middle of the area and in the Gulf of Ulloa (Fig. 1). High surface salinities were also associated with coastal upwelling only in April and July.

Surface circulation had a strong influence on the thermohaline properties described above (Goericke et al. 2005, Peterson et al. 2006). We briefly summarize surface circulation in 2005 in order to distinguish mesoscale structures. The weakest equatorward flow was observed in January. In this month, surface circulation was split in 2 regions: in the north, an intrusion of subarctic offshore water occurred (see arrows in Fig. 4), bending to the north and approaching the coast, whereas in the remaining area, the equatorial water flowed meandering toward the south. In spring, the circulation changed with the strengthening of the $\mathrm{CC}$, which progressed near the coast along the Baja California peninsula. A semicircle in the southwest portion suggested the presence of an anticyclonic eddy of equatorial water. The CC flow was also intense in July but was more separated from the coast. The CC was still more separated in the central part where a large cyclonic eddy (150 km in diameter) was formed. In the northern region, a pair of eddies spinning in opposite directions was detected on both sides of the CC flow, with the cyclonic eddy being located near the coast and the anticyclonic eddy being offshore. In October, a weakened and meandering CC flowed far away from coast. In the northern region, a small eddy was observed between Punta Baja and Guadalupe Island.

\section{Seasonal variability in hyperiid species}

The nighttime samples collected in 2005 contained 115 species of hyperiid amphipods, 57 of which were rare, occurring in $<10 \%$ of the samples (Appendix 1). Considering only the species with positive records in $>25 \%$ of the samples reduces the list to 34 species (Fig. 2), with only 12 of these being very frequent ( $>50 \%$ of the samples).

Seasonal variability in species composition was high in 2005. Population density of the species changed throughout the year, with only 3 dominant species (Vibilia armata, Eupronoe minuta, and Primno brevidens) remaining among the top 5 in all seasons (Fig. 2). Except in January, the geometric mean of these species remained at $>10$ ind. $1000 \mathrm{~m}^{-3}$. This value is apparently low since abundance ranged from 0 to $>1000$ ind. $1000 \mathrm{~m}^{-3}$ for $V$. armata and P. brevidens. Sixteen other species showed maximum captures that were $>100$ ind. $1000 \mathrm{~m}^{-3}$.

ANOVA for abundances among seasons produced significant results in $71 \%$ of the most common species (>10\% presence in some cruises; Table 1 ). Tukey's test indicated that most of the species had a tendency to increase during the year. Some species such as Vibilia armata had a minimum abundance in winter but high abundance during the rest of the year, while other species with low abundance from winter to summer rebounded in autumn (e.g. Themistella fusca). Eupronoe minuta and 10 other species showed a gradual increase during the year. The species with the strongest increasing tendency in their abundance from winter to autumn were Primno brevidens and, remarkably, Lestrigonus schizogeneios and L. bengalensis, the latter two ranking first and second respectively in October (Fig. 2).

A few species exhibited the opposite tendency, the most distinctive of which were Anchylomera blossevillei and Phronimopsis spinifera (Table 1). Their geometric means in January 2005 were apparently low ( 4 and 2 ind. $1000 \mathrm{~m}^{-3}$ respectively) due to their scarce presence in the southern stations. However, in the north, A. blossevillei and P. spinifera reached 149 and 143 ind. $1000 \mathrm{~m}^{-3}$ respectively in January, compared with maximal captures of 12 and 4 ind. $1000 \mathrm{~m}^{-3}$ respectively in October 2005. 

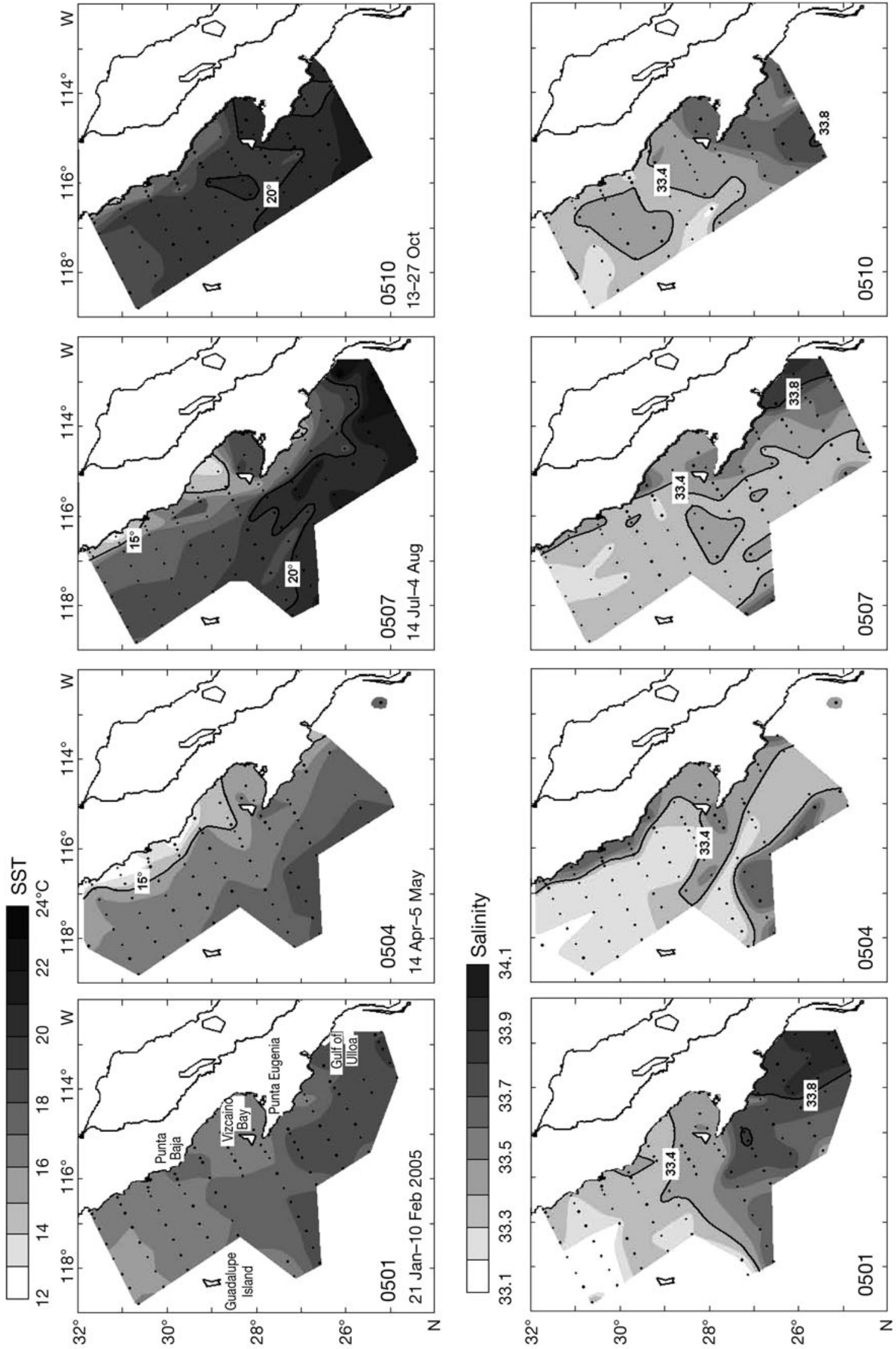

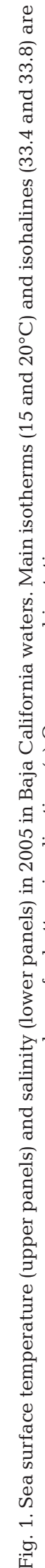




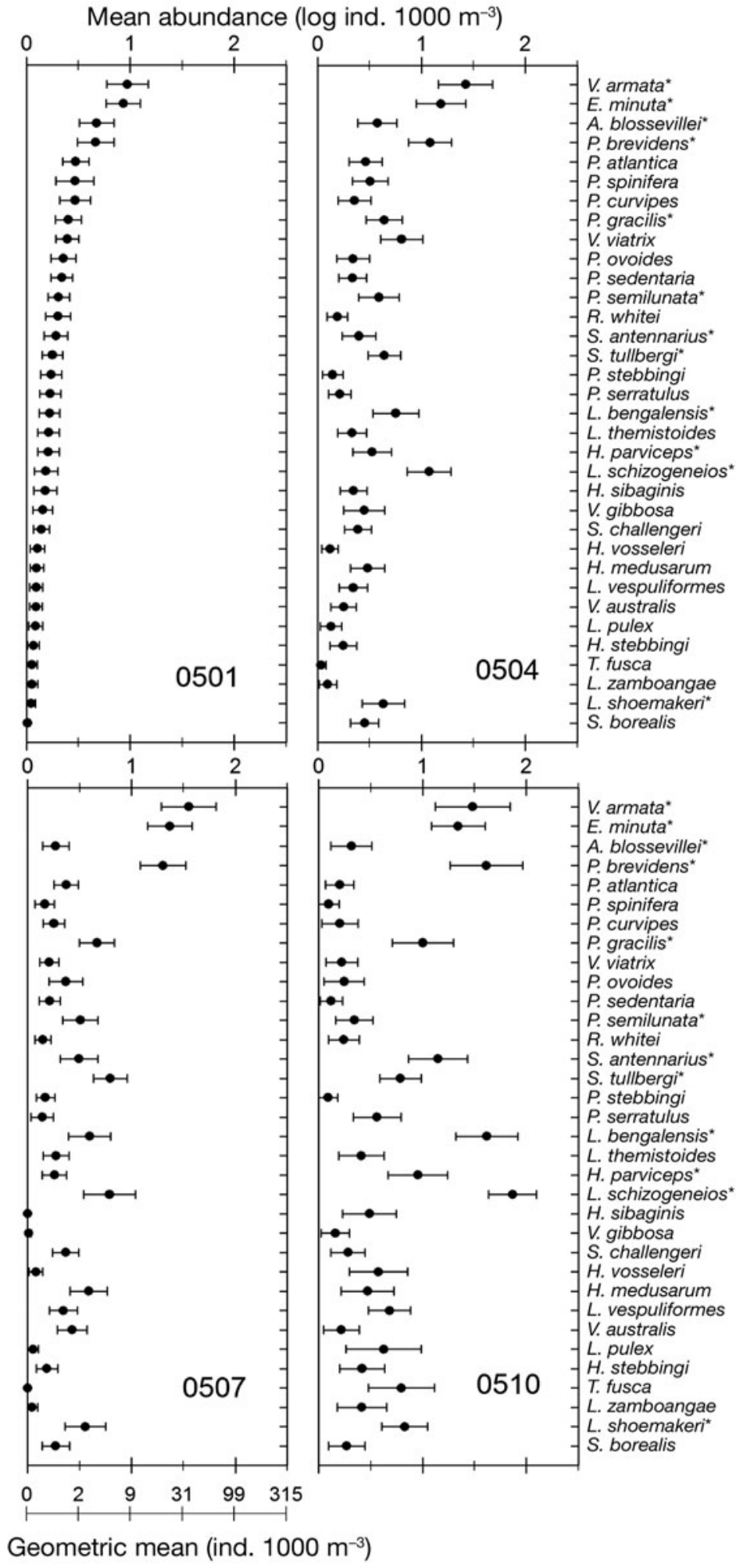

Fig. 2. Mean abundance and 95\% CI of hyperiid species. The 34 species shown are a combination of the 20 most abundant species from each season, listed in decreasing order of abundance as observed in winter 2005 (Cruise 0501) to show the progressive modification of the community structure through spring (Cruise 0504) summer (Cruise 0507), and autumn (Cruise 0510) ( $\mathrm{N}=52,39,41,41$ respectively). Data were log transformed and the additional $x$-axis shows the scale for the retransformed mean. ( ${ }^{*}$ ) Dominant species, i.e. species present in $>50 \%$ of samples from one or more cruises. For full species names see Table 1 or Appendix 1

\section{Amphipod community in relation to mesoscale structures}

Seasonal change did not only involve temporal contrasts in abundance; movements between coastal and offshore waters were also important. Although the oceanic habit of hyperiid amphipods is well known, they advanced some distance toward the coast when the currents weakened. This was particularly evident in October at the coastal shelf of Vizcaino Bay, where hyperiid captures were $0-68$ ind. $1000 \mathrm{~m}^{-3}$ from January to July, and increased to $272-1154$ ind. $1000 \mathrm{~m}^{-3}$ in October.

Apart from the onshore-offshore seasonal differences, latitudinal displacements of species were evident, and circulation features influenced amphipod distribution throughout the year. Multivariate analysis relating the similarity of sampling points produced a dendrogram that highlighted a large assemblage of 67 oceanographic stations (Cluster 1) with $52 \%$ similarity (Fig. 3a). No samples from January were included in this large cluster, indicating a winter community that was different from the rest of the seasons. Cluster 1 contained 3 subgroups that were closely related in the NMS ordination (Fig. 3b). The geographic influence of Cluster 1 had an extended latitudinal domain (Fig. 4). Two of the subgroups (1A and 1C) were almost exclusive to 1 season (spring and autumn respectively), while Subgroup 1B included 3 cruises. Since the stations of Subgroup 1B were located along the main current flow in April and July, and off north Baja California in October, this subgroup represents the characteristic composition of the $\mathrm{CC}$, with 3 species (Vibilia armata, Eupronoe minuta, and Primno brevidens) sharing dominance in equal proportions (Fig. 5). The proportions of these 3 species changed in the other subgroups of the cluster, with higher dominance of $V$. armata in Subgroup 1A that was located in the middle of the area at the eastern side of the CC flow (Fig. 4). In Subgroup 1C that embraced the entire central region, the highest dominance was attributed to Lestrigonus schizogeneios and L. bengalensis. 
Table 1. Seasonal variation in population density of hyperiid species. ANOVAs with significant results $(\alpha=0.05)$ (in bold) were subjected to a posteriori contrasts using Tukey's test to determine seasonal tendencies. Cases: (A) only 1 cruise was significantly different from the rest, (B) differences were observed between the extremes of the year (January vs. October), (C) differences were observed between the extremes of the year (January and October) and other seasons (April and/or July), (D) double pulses of increase were observed in April and October (significantly higher than January or/and July), (E) other pattern, and (F) no apparent seasonality. Data were log transformed

The next cluster (2) was common in January and April but the stations involved had different geographic domains in each month. For winter, clustered stations were from the first and fourth northern transects, while they were in the middle of the area offshore of the CC flow in spring (Fig. 4). The main difference of Cluster 2 from Cluster 1 was the low contribution of Lestrigonus schizogeneios, which was surpassed by Anchylomera blossevillei (Fig. 5). Other abundant species not shown in Fig. 5 were Phrosina semilunata, Phronima atlantica, and Phronima curvipes, which together represent $17 \%$ of the hyperiids in Cluster 2 .

The third cluster was characteristic of the northern region, with 2 subgroups: one for winter (3A) and the other for summer (3B). In both cases, but most clearly in subgroup 3B, the influence of a cyclonic eddy is observable (Figs. 3 \& 4). The abundance of the main species (Vibilia armata, Eupronoe minuta and Primno brevidens) was still important, although $V$. armata was particularly higher in Subgroup 3B (Fig. 5). Being isolated from oceanic water, Subgroup 3B contained few amphipods of the species Anchylomera blossevillei and Phronimopsis spinifera, which were secondarily important in Subgroup 3A.

The other 4 clusters identified in the dendrogram (Clusters 4 to 7 ) were also confirmed, with $<40 \%$ similarity (Fig. 3a). Stations from these clusters dispersed toward the periphery in the NMS ordination (Fig. 3b). However, their geographic zones of influence and

\begin{tabular}{|c|c|c|c|}
\hline $\begin{array}{l}\text { Case } \\
\text { Seasonal tendency }\end{array}$ & Species & F & $\mathrm{p}$ \\
\hline \multicolumn{4}{|l|}{ Case A } \\
\hline Winter maximum & Anchylomera blossevillei & 5.8 & 0.001 \\
\hline Winter minimum & Hyperoche medusarum & 18.2 & $<0.001$ \\
\hline " & Lestrigonus shoemakeri & 22.2 & $<0.001$ \\
\hline$"$ & Scina tullbergi & 28.2 & $<0.001$ \\
\hline " & Streetsia challengeri & 4.6 & 0.004 \\
\hline " & Vibilia armata & 5.5 & 0.001 \\
\hline Spring maximum & Iulopis mirabilis & 6.7 & $<0.001$ \\
\hline & Lycaea pachypoda & 7.2 & $<0.001$ \\
\hline " & Vibilia gibbosa & 9.5 & $<0.001$ \\
\hline " & Vibilia viatrix & 17.3 & $<0.001$ \\
\hline Autumn maximum & Eupronoe maculata & 13.5 & $<0.001$ \\
\hline " & Hyperietta vosseleri & 7.8 & $<0.001$ \\
\hline " & Lestrigonus macrophthalmus & 9.0 & $<0.001$ \\
\hline$"$ & Lycaea pulex & 15.9 & $<0.001$ \\
\hline " & Lycaeopsis zamboangae & 13.7 & $<0.001$ \\
\hline " & Paraphronima gracilis & 9.6 & $<0.001$ \\
\hline " & Platyscelus serratulus & 9.8 & $<0.001$ \\
\hline$"$ & Simorhynchotus antennarius & 23.8 & $<0.001$ \\
\hline " & Themistella fusca & 50.1 & $<0.001$ \\
\hline " & Vibilia stebbingi & 6.2 & $<0.001$ \\
\hline \multicolumn{4}{|l|}{ Case B } \\
\hline Gradual decrease & Phronima atlantica & 4.0 & 0.009 \\
\hline " & Phronima curvipes & 3.2 & 0.024 \\
\hline " & Phronima sedentaria & 4.2 & 0.007 \\
\hline Gradual increase & Amphithyrus sculpturatus & 3.5 & 0.016 \\
\hline " & Brachyscelus crusculum & 2.8 & 0.040 \\
\hline " & Brachyscelus globiceps & 4.4 & 0.005 \\
\hline$"$ & Eupronoe armata & 3.3 & 0.021 \\
\hline$"$ & Eupronoe minuta & 4.7 & 0.004 \\
\hline " & Oxycephalus clausi & 4.4 & 0.005 \\
\hline " & Parapronoe campbelli & 3.2 & 0.023 \\
\hline " & Parapronoe parva & 4.2 & 0.007 \\
\hline " & Parascelus typhoides & 2.9 & 0.035 \\
\hline " & Tryphana malmi & 3.7 & 0.012 \\
\hline \multirow{2}{*}{\multicolumn{4}{|c|}{ Case C }} \\
\hline & & & \\
\hline Drastic decrease & Phronimopsis spinifera & 8.2 & $<0.001$ \\
\hline Drastic increase & Laxohyperia vespuliformis & 18.5 & $<0.001$ \\
\hline " & Lestrigonus bengalensis & 45.7 & $<0.001$ \\
\hline " & Lestrigonus schizogeneios & 63.2 & $<0.001$ \\
\hline " & Paraphronima crassipes & 10.9 & $<0.001$ \\
\hline$"$ & Primno brevidens & 16.2 & $<0.001$ \\
\hline \multicolumn{4}{|l|}{ Case D } \\
\hline Oct pulse $=$ Apr pulse & Hyperietta stebbingi & 11.7 & $<0.001$ \\
\hline & Hyperietta stephenseni & 21.2 & $<0.001$ \\
\hline " & Hyperiodes sibaginis & 6.0 & 0.001 \\
\hline " & Parascelus edwardsi & 4.6 & 0.004 \\
\hline Oct pulse $>$ Apr pulse & Hyperietta parviceps & 10.0 & $<0.001$ \\
\hline \multicolumn{4}{|l|}{ Case E } \\
\hline Apr $>$ Jan & Phrosina semilunata & 3.4 & 0.018 \\
\hline Jul > Oct & Vibilia australis & 6.9 & $<0.001$ \\
\hline \multicolumn{4}{|l|}{ Case F } \\
\hline & Calamorhynchus pellucidus & 0.9 & 0.455 \\
\hline & Dairella californica & 1.6 & 0.199 \\
\hline & Glossocephalus milneedwardsi & 1.0 & 0.407 \\
\hline & Hemityphis tenuimanus & 2.5 & 0.063 \\
\hline & Hyperoche cryptodactylus & 1.3 & 0.267 \\
\hline & Hyperioides longipes & 2.6 & 0.056 \\
\hline & Lycaea serrata & 1.1 & 0.361 \\
\hline & Lycaeopsis themistoides & 1.9 & 0.131 \\
\hline & Oxycephalus piscator & 0.3 & 0.830 \\
\hline & Parapronoe crustulum & 0.6 & 0.589 \\
\hline & Phronima pacifica & 1.7 & 0.163 \\
\hline & Phronima stebbingi & 2.1 & 0.103 \\
\hline & Phronimella elongata & 2.3 & 0.078 \\
\hline & Platyscelus ovoides & 0.6 & 0.594 \\
\hline & Pronoe capito & 0.7 & 0.579 \\
\hline & Rhabdosoma whitei & 1.9 & 0.137 \\
\hline & Scina borealis & 2.4 & 0.070 \\
\hline & Scina stenopus & 0.4 & 0.768 \\
\hline & Streetsia steenstrupi & 0.5 & 0.673 \\
\hline
\end{tabular}


seasonal incidence were well defined (Fig. 4). Cluster 4 was a clearly equatorial assemblage confined to stations near the Gulf of Ulloa in July and October. The distinctive mark of this cluster was the species Hyperioides longipes, although Primno brevidens and Lestrigonus bengalensis were also abundant (Fig. 5).

In contrast to previous groups, a low number of amphipods characterized inner stations belonging to Clusters 6 and 7 as well as oceanic stations in Cluster 5 (Figs. 4). Most locations in Cluster 5 were from January and April cruises but all the 3 subgroups were well represented only in winter. The 3 subgroups presented a layout that was parallel to the coast in winter, with Subgroup 5A being adjacent to the Vizcaino coastal shelf, followed by $5 \mathrm{C}$ in the middle stations and then $5 \mathrm{~B}$ offshore. The influence of oceanic species permeated Cluster 5 (as in Cluster 2), with more influence of $A n$ - chylomera blossevillei in Subgroup 5A, Platyscelus ovoides in $5 \mathrm{~B}$ and Vibilia viatrix in $5 \mathrm{C}$ (Fig. 5). The oceanic Subgroup 5B also occupied 2 offshore stations in July and the anticyclonic eddy observed in April.

Finally, the coastal Clusters 6 and 7 had the lowest abundance of amphipods. Most of the stations in Cluster 6 were adjacent to the Gulf of Ulloa in January, while stations of Cluster 7 were primarily near the coast of north Baja California in April (Fig. 4). Apart from Eupronoe minuta and Primno brevidens, the amphipods Hyperiodes sibaginis, Platyscelus serratulus and Phronima sedentaria were common in Cluster 6, while Hyperoche medusarum and Scina tullbergi were the most common species in Cluster 7.

Rarefaction curves estimated with all the species showed maximal diversity in Clusters 2 and 5C (Fig. 6), suggesting a mixture of the $\mathrm{CC}$ community and

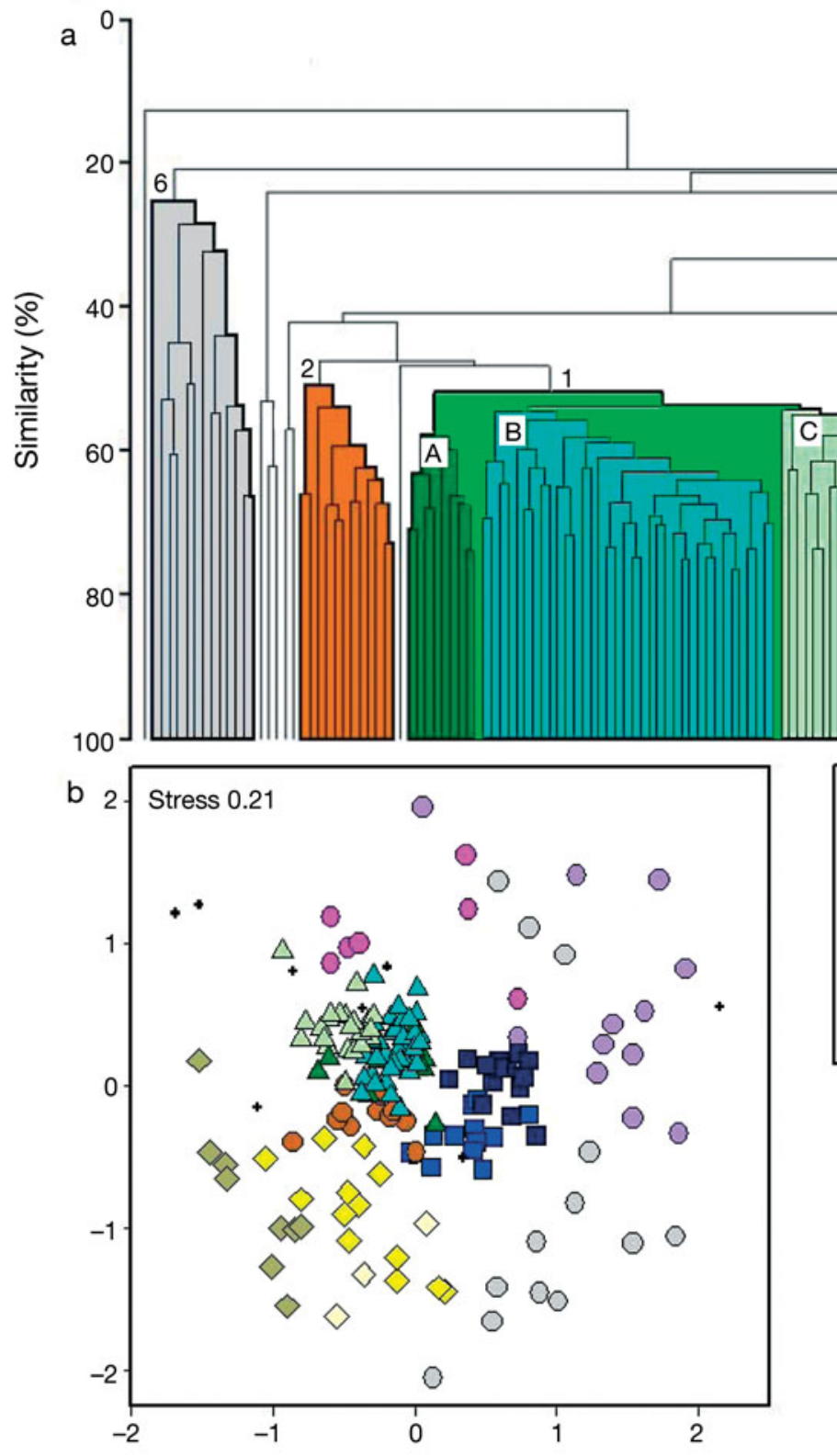

Fig. 3. Cluster analysis of hyperiid species composition in 170 sampling stations from 4 cruises in 2005: (a) dendrogram, (b) NMS (nonmetric multidimensional scaling) ordination. Colors indicate clusters (1 to 7 ) and subgroups (A to C) (geographic positions of the stations are shown in Fig. 4) 

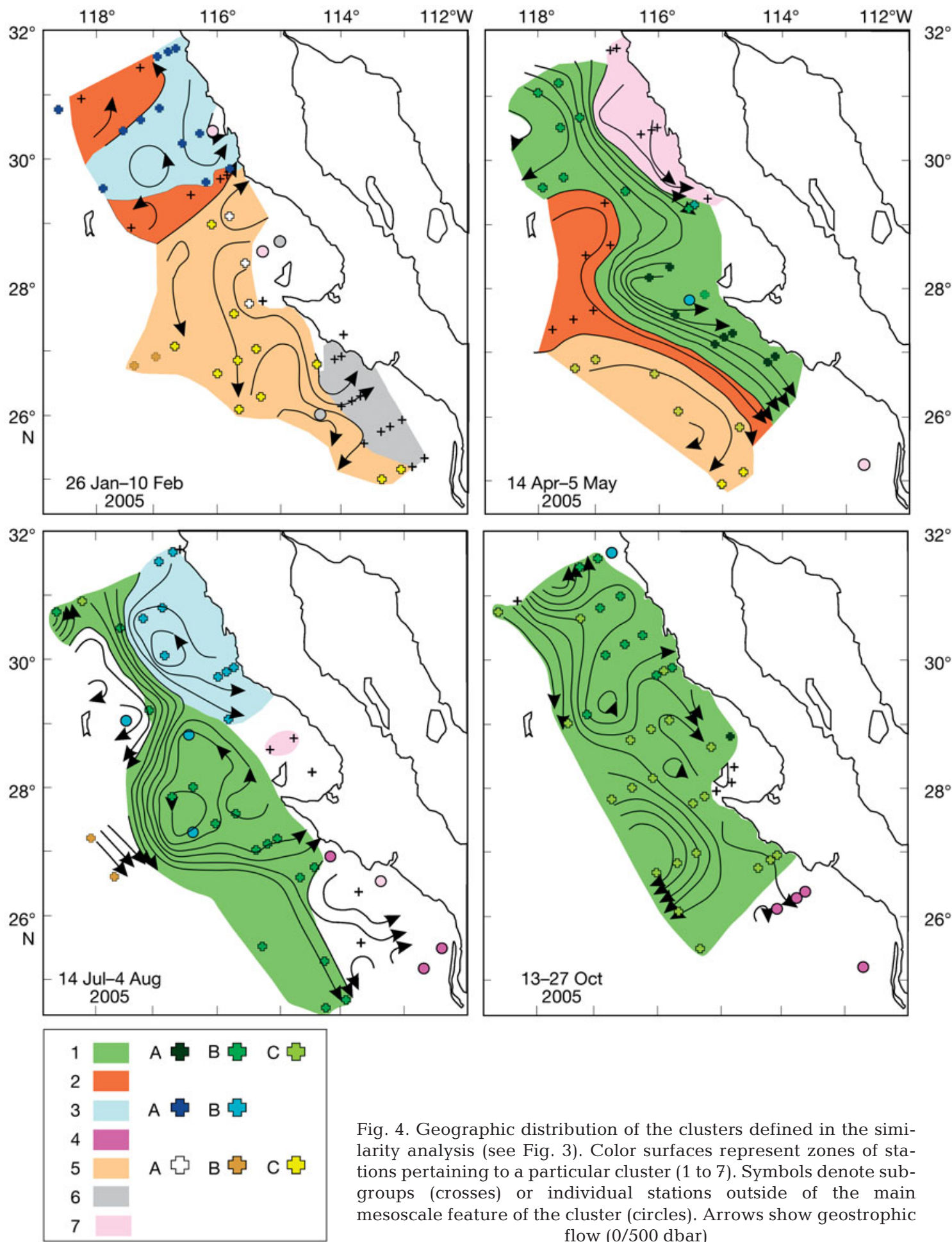

Fig. 4. Geographic distribution of the clusters defined in the similarity analysis (see Fig. 3). Color surfaces represent zones of stations pertaining to a particular cluster (1 to 7). Symbols denote subgroups (crosses) or individual stations outside of the main mesoscale feature of the cluster (circles). Arrows show geostrophic flow $(0 / 500$ dbar $)$

oceanic species carried by oligotrophic waters entering onshore in January 2005. Cluster 6 was the third most diverse and was influenced by tropical species from the southeast. Cluster 1, which is representative of the $\mathrm{CC}$ flow, had intermediate diversity, with the more oceanic subgroup (1C) being slightly more diverse. Clusters $3 \mathrm{~A}$ and $5 \mathrm{~B}$ also had intermediate diversity.
Cluster 3B corresponded to the coolest parcel of the CC flow, while Cluster 5B was associated with the anticyclonic eddy. Two relatively coastal clusters (3B and 5A) were the least diverse, with Cluster 3B being associated with a cyclonic eddy, and 5A with the Vizcaino coastal shelf. This low diversity is due to the high dominance of Vibilia armata (Fig. 5). Unexpectedly, the 


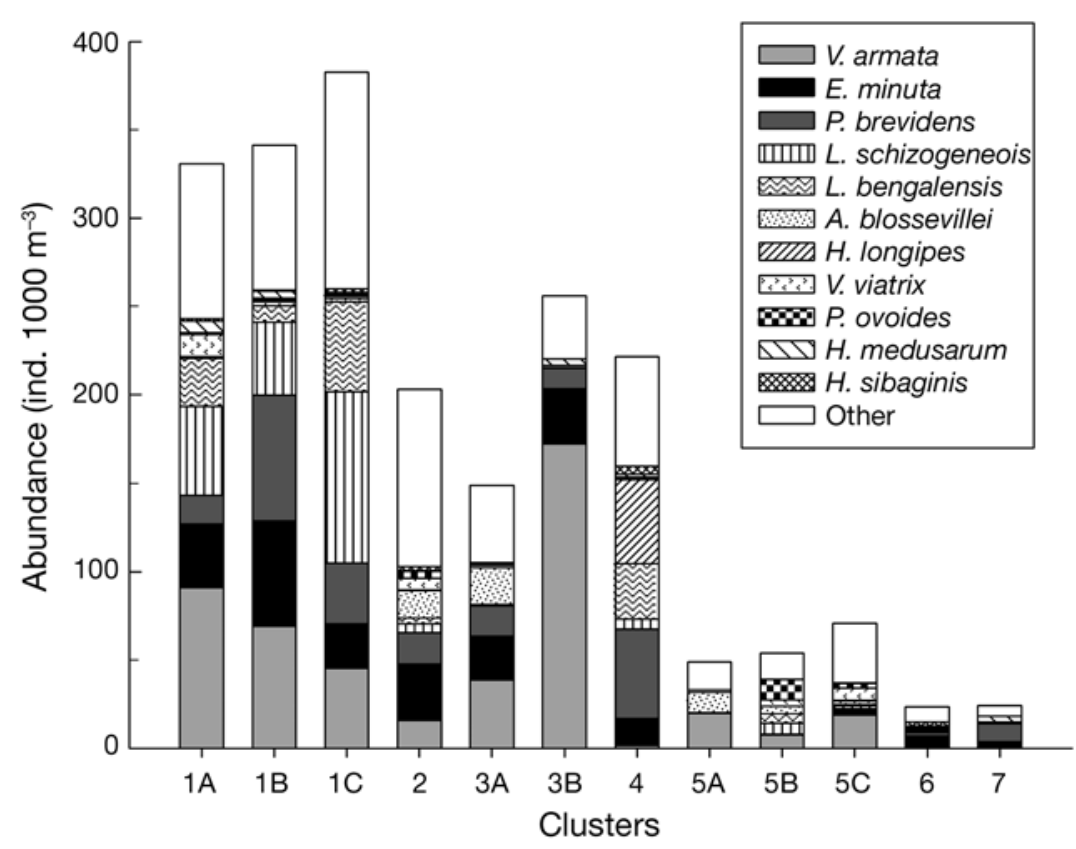

Fig. 5. Stacked geometric means of hyperiid species abundances in the clusters (see Fig. 3). The species shown are a combination of the 2 most abundant species from each cluster. For full species names see Table 1 or Appendix 1 between January and April. Further, salps suffered a dramatic decrease of 2 orders of magnitude in July. Although salp abundance recovered in October, abundance did not reach the levels attained at the beginning of the year. Even if the carbon content of salps were considered, the contrast between winter-spring and summerautumn would still be strong, due to the high biomass of Salpa fusiformis, which is one of the largest species that were dominant in January to April.

Independently of the global salp abundance, particular species could be critical for certain amphipod species. The correlation between 66 hyperiid species and the 7 most common salp species resulted in 462 coefficients, with only $8 \%$ being highly significant ( $\alpha=0.001$; Table 2 ). Cyclosalpa danae had the maximum number of significant correlations with amphipods. This salp was exclusively from October, and correlated with 7 of the 12 most dominant hyperiid species during this month.

diversity of the most tropical cluster (4) was similar to that of coastal Cluster 7, although species abundances within both groups were strongly different.

\section{Correlation between hyperiid amphipods and salps}

Salps had maximal abundance in spring (Fig. 7), and this could explain the two-fold increase in amphipods

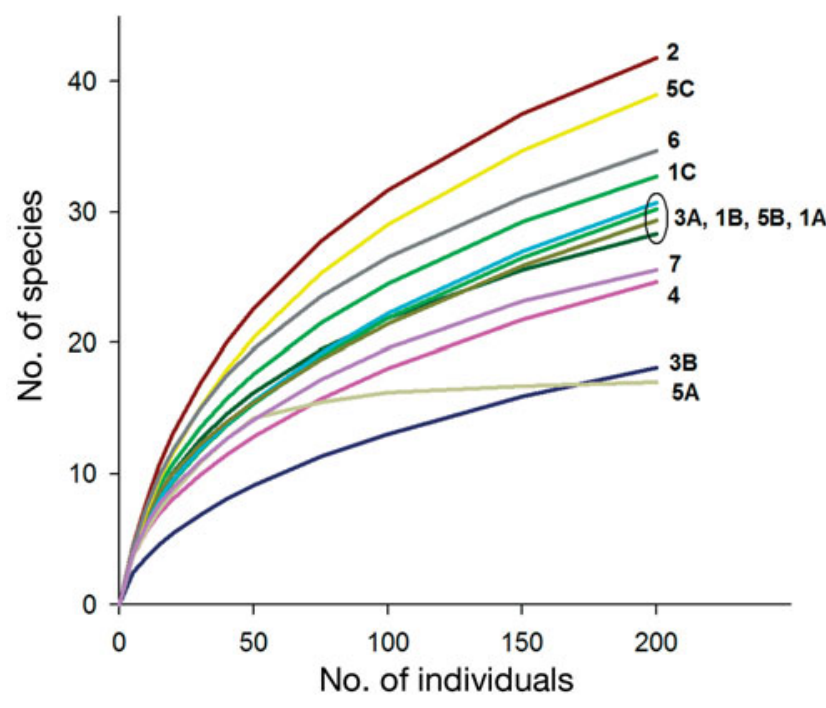

Fig. 6. Rarefaction curves based on the cumulative number of individuals aggregated as a function of the clusters shown in Fig. 3. All 115 species were included
Hyperiids had significant correlations with 1 or 2 salp species (Table 2). Vibilia was one of the genera with more correlated salp species in the list. Closer inspection of the seasonal tendency (Table 1) showed that species associated with cool waters ( $V$. gibbosa and $V$. viatrix) correlated with Salpa fusiformis and Thalia orientalis (Table 2), or in the case of $V$. australis, with Cyclosalpa bakeri. In contrast, species associated with warm waters (V. chuni and V. stebbingi) corre-

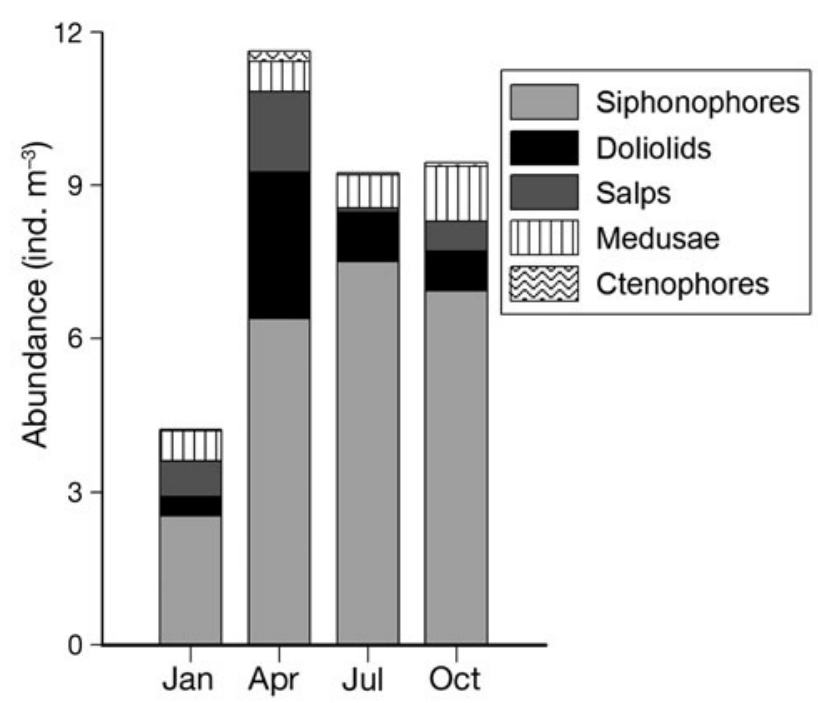

Fig. 7. Stacked geometric means of the abundances of gelatinous taxa during the 4 seasons in 2005 
Table 2. Spearman correlation coefficients between the abundances of hyperiid and salp species. Only species with highly significant correlations are shown $(\alpha=0.001 ; \mathrm{N}=173)$

\begin{tabular}{|c|c|c|c|c|c|c|c|}
\hline Amphipod species & $\begin{array}{c}\text { Cyclosalpa } \\
\text { bakeri }\end{array}$ & $\begin{array}{c}\text { Cyclosalpa } \\
\text { danae }\end{array}$ & $\begin{array}{c}\text { Salpa } \\
\text { fusiformis }\end{array}$ & $\begin{array}{l}\text { Thalia } \\
\text { cicar }\end{array}$ & $\begin{array}{c}\text { Thalia } \\
\text { democratica }\end{array}$ & $\begin{array}{c}\text { Thalia } \\
\text { orientalis }\end{array}$ & $\begin{array}{c}\text { Weelia } \\
\text { cylindrica }\end{array}$ \\
\hline Amphithyrus sculpturatus & & & & 0.261 & & & \\
\hline Eupronoe maculata & & & & 0.347 & & & 0.273 \\
\hline Hemithyphis tenuimanus & & 0.300 & & & & & \\
\hline Hyperietta parviceps & & 0.317 & & & 0.336 & & \\
\hline Hyperietta stephenseni & & & & & 0.304 & & \\
\hline Hyperioides longipes & & & & 0.338 & & & \\
\hline Hyperioides sibaginis & & & & & & 0.330 & \\
\hline Hyperoche medusarum & 0.272 & & & & & & \\
\hline Laxohyperia vespuliformes & & 0.310 & & & & & \\
\hline Lestrigonus bengalensis & & 0.257 & & & & & \\
\hline Lestrigonus macrophthalmus & & 0.304 & & & & & \\
\hline Lestrigonus schizogeneios & & 0.313 & & & 0.270 & & \\
\hline Lycaea pulex & & & & 0.328 & & & 0.394 \\
\hline Lycaeopsis zamboangae & & 0.329 & & & & & 0.252 \\
\hline Oxycephalus clausi & & & 0.284 & & & & \\
\hline Paraphronima gracilis & & & & & & -0.278 & \\
\hline Phronima curvipes & & & 0.267 & & & & \\
\hline Phronima sedentaria & & & 0.313 & & & & \\
\hline Primno brevidens & & 0.255 & & & & -0.370 & \\
\hline Simorhynchotus antennarius & & 0.300 & & & 0.276 & & \\
\hline Themistella fusca & & 0.275 & & & 0.319 & & \\
\hline Tryphana malmi & & & & & & -0.361 & \\
\hline Vibilia australis & 0.398 & & & & & & \\
\hline Vibilia chuni & & & & 0.343 & & & 0.267 \\
\hline Vibilia gibbosa & & & 0.403 & & & 0.301 & \\
\hline Vibilia stebbingi & & & & 0.291 & & & 0.352 \\
\hline Vibilia viatrix & & & 0.394 & & & 0.425 & \\
\hline Total correlations & 2 & 10 & 5 & 6 & 5 & 6 & 5 \\
\hline
\end{tabular}

lated with tropical salp species (Thalia cicar and Weelia cylindrica). Significant coefficients were relatively low. The highest Spearman correlation, which was between $V$. viatrix and $T$. orientalis $(\mathrm{r}=0.425)$, suggests that the presence of $T$. orientalis could explain only $18 \%$ of the abundance of $V$. viatrix, and less for all other species.

Other gelatinous zooplankton were also abundant in 2005 (Fig. 7), particularly doliolids and ctenophores in April and siphonophores year round. Abundances of these gelatinous taxa were higher relative to those in 1998 to 2005, as could be confirmed by positive abundance anomalies in 2005 (Fig. 8). The only exception was July 2005 when only siphonophores had a high positive anomaly. Therefore, the increase in salps and in the rest of the gelatinous taxa in October might have been pivotal in the explosion of hyperiid populations.

\section{DISCUSSION}

The present study is a contribution to the ecological characterization of hyperiid amphipod communities in a wide subtropical area within the CC. The cluster analysis confirmed that the main stream of the CC was dominated by 3 species (Vibilia armata, Eupronoe minuta, and Primno brevidens) year round. The dominance and proportionate balance of these 3 species in the Baja California waters is a regional characteristic which is also observed southern California (Lavaniegos \& Ohman 1999, 2003). Differences in the amphipod community emerge in northern sectors of the CC. Off central California, the difference lies in a diminished population density of E. minuta, while $V$. armata and $P$. brevidens remain within the pool of dominant species (Lavaniegos 2007). Further north, in the latitudes of Oregon, the hyperiids $V$. armata and $P$. brevidens become secondary species, while Primo macropa and 2 other temperate species (Themisto pacifica and Paraphronima gracilis) dominate the community (Lorz \& Pearcy 1975). In the present study, P. gracilis was particularly frequent in October despite the high temperatures recorded in surface waters, while $T$. pacifica was a rare species that was restricted to the colder months of January and April 2005.

Many hyperiid species that were found off the western coast of Baja California in this study also occurred in the Gulf of California (Siegel-Causey 1982). The 


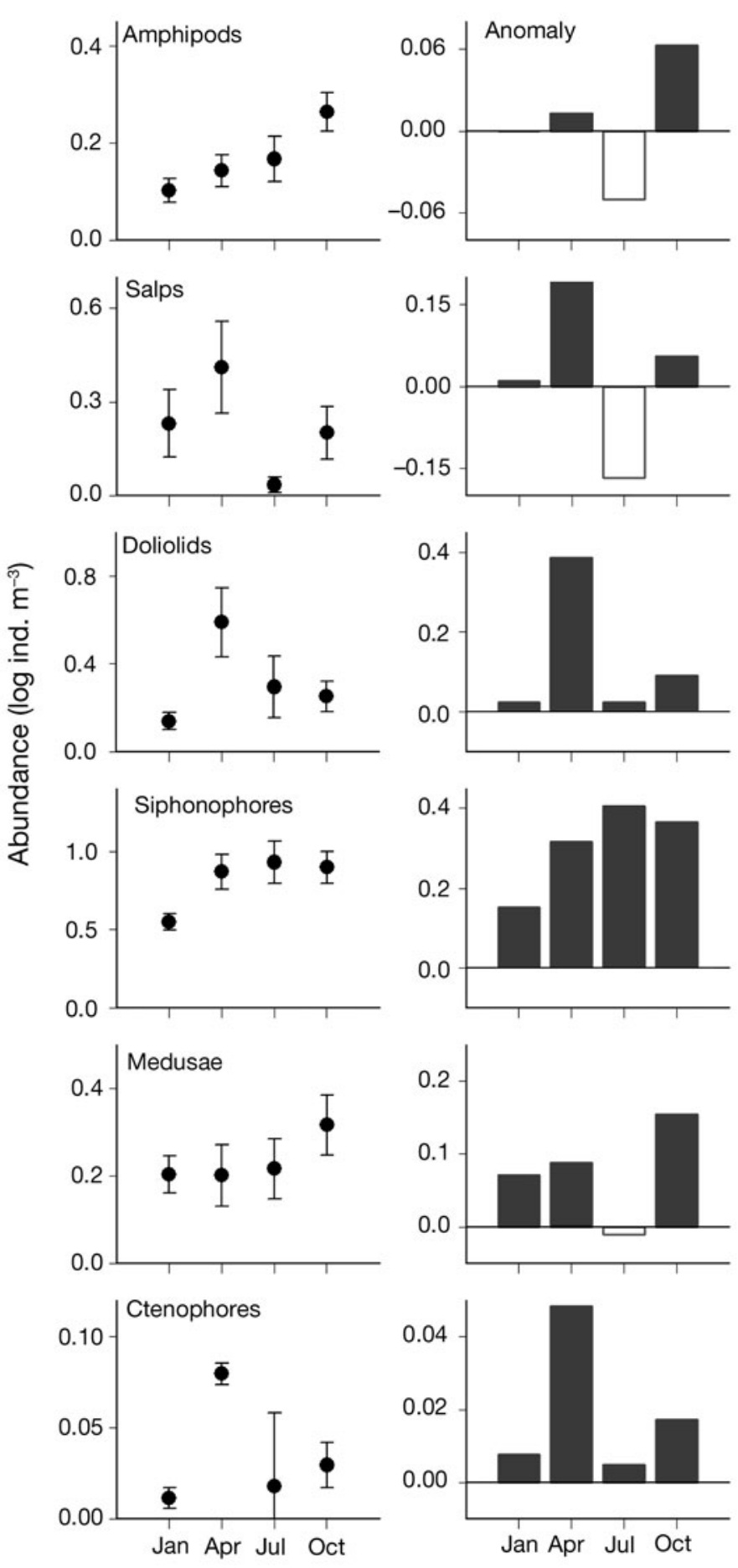

was surpassed by tropical members of this genus (E. maculata, E. armata). Although taxonomic confusion would be possible between the very similar $E$. minuta and E. armata, both were in the rank of dominant species. Apparently, they prefer oceanic waters, and were particularly abundant in the North Pacific gyre along with other Eupronoe spp. (Shulenberger 1977).

The amphipods analyzed by Siegel-Causey (1982) were mainly from the 1956-1957 Gulf of California cruises. Many species found at the entrance of the gulf increased and penetrated into the gulf during the summer of 1957, occupying the most northern regions in some cases (Lestrigonus bengalensis, L. shoemakeri, Simorhynchotus antennarius, Parascelus [Thyropus] edwardsi). This appeared to be a tropical expansion due to the influence of the strong 1957-1959 El Niño. Therefore, the preeminence of $L$. bengalensis as a top species in the gulf could indicate interannual variability. However, the distribution of this tropical species appears to be notably wide as it has been observed dominating relatively coastal environments in the eastern Pacific (Gasca \& FrancoGordo 2008), and was significantly abundant in oceanic offshore regions of the North Pacific gyre (Shulenberger 1977). All these studies are not readily comparable due to differences in the type of nets used ( $1 \mathrm{~m}$ ring with bridles or bongo) and tow depths (between 140 and $200 \mathrm{~m}$ ). Other net gears such as the Isaac-Kidd Midwater Trawl (IKMT) of large dimensions are towed more rapidly, filter large volumes of water, and may be more efficient in capturing large size amphipods. For example, Repelin (1978) used IKMT and an Omori net (1.6 m diameter and $333 \mu \mathrm{m}$ mesh) to collect hyperiids throughout the equatorial Pacific. He obtained maximal occurrence frequencies (82 to $95 \%$ ) for species of the family Phronimidae (Phronima sedentaria, P. atlantica, P. pacifica, Phronimella elongata) and Phrosina semilunata from the IKMT hauls, compared to only 25 to $60 \%$ occurrence frequencies for the same species with the Omori net. In contrast, Eupronoe minuta had a frequency of $44 \%$ with the Omori net against only $8 \%$ with the IKMT.

\section{Amphipod assemblages and mesoscale structures}

The coupling between surface circulation (0/ 500 dbar) and hyperiid assemblages (in the upper $200 \mathrm{~m}$ ) was evident in the multivariate analysis, with remarkable faunal differences in most of the mesoscale structures observed throughout 2005. For example, the most abundant species year round in the gulf was Lestrigonus bengalensis, followed by Primno brevidens, L. shoemakeri and Vibilia armata. In contrast, Eupronoe minuta was a rare species in the gulf, and 
separation of assemblages into 2 clusters (2 and 3A) off north Baja California in January showed the influence of oligotrophic waters surrounding the meander of the CC (Fig. 4), and supports the geostrophic flow described by Goericke et al. (2005). The meander is part of the large southern California eddy which has been named the 'Ensenada Front' (Haury et al. 1993, Venrick 2000). In the present study, Cluster 2 was the most diverse (Fig. 6) due to the mixing of $\mathrm{CC}$ and oligotrophic waters (Ensenada Front). The fauna south of the front was exclusive to the winter, reflecting a strong oceanic influence that was not observed in the following seasons.

It is important to point out the oceanic habitat of hyperiid amphipods. The upwelling season in April 2005 produced the most productive area adjacent to the northern Baja California coast, with high chlorophyll and zooplankton biomass (Peterson et al. 2006, Lavaniegos et al. 2008). However, amphipods were scarce only in the most productive area (Cluster 7; Fig. 5). This fact reinforces the oligotrophic habitat requirement of amphipods (Vinogradov 1991). However, Henson \& Thomas (2007) showed that the CC presents a secondary productive peak during autumn and winter in the oceanic domain, while the main productive peak occurs during spring and summer in coastal waters. This means that the bulk of amphipod species are adapted to reproduce at the end of summer and during autumn (Table 1), receiving the benefits of the offshore productivity.

A peculiarity of the upwelling activity during 2005 was a delay in some regions of the CC system, which contrasted with continued upwelling activity in autumn (Schwing et al. 2006). Schwing et al. (2006) excluded the Baja California region from their analysis. The Bakun upwelling indices for Baja California did not show a delay in coastal upwelling during spring but shared the second pulse of high values in autumn with northern sectors (www.pfel.noaa.gov/ products/products.html). In contrast, downwelling was observed during winter, which explained the low abundances of amphipods. This suggests that downwelling could have progressed from south to north in spring, thereby affecting the northern regions of the CC. The CC strengthened off Baja California in spring, as shown by the increase in several amphipod species associated with cool temperatures (e.g. Hyperoche medusarum, Vibilia viatrix, and $V$. australis) and also by the significant presence of subarctic euphausiids (Lavaniegos in press). The increase in temperate species in the Baja Californian sector of the $\mathrm{CC}$ during spring contrasts with the low biological productivity upstream from southern British Columbia to northern California (Mackas et al. 2006, Sydeman et al. 2006).
Apart from the strong upwelling pulses, mesoscale structures such as eddies could be linked with productive areas in the open sea that provide favorable habitats for amphipods. Classic studies in eddies show increased productivity that is driven by the input of nutrients in the periphery of cyclonic eddies, which contrasts with poor productivity in anticyclonic eddies (Hormazabal et al. 2004, Prasanna-Kumar et al. 2004, Aristegui \& Montero 2005). Our results are in agreement with this pattern. In a cyclonic eddy, we found a strong dominance of Vibilia armata and a low diversity, while high diversity but low population densities were observed in the anticyclonic eddy.

The distance of eddies from the coast also affects species composition. In the present study, the second and larger cyclonic eddy affecting a considerable area off central Baja California was indistinguishable from the main CC flow. Cyclogenesis is obviously important in the thermohaline characteristics and dynamics of eddies. In the Gulf of Alaska, anticyclonic eddies (Haida) are formed near the coast and have high concentrations of chlorophyll and herbivores (Batten \& Crawford 2005). Apparently, the Haida eddies are colonized by offshore species as they move to the open sea (Mackas et al. 2005). The anticyclonic eddy observed off Baja California in April 2005 has a different origin, being formed within offshore equatorial waters, remaining to the west of the $\mathrm{CC}$ flow, and maintaining a minor but diverse amphipod tropical assemblage. This is a recurrent anticyclone, and its formation has been explained by the geometry of the coastline (Soto-Mardones et al. 2004). This anticyclone could prevent the propagation of tropical species toward the coast when the $\mathrm{CC}$ is strong, as suggested by the present analysis.

\section{Relation between hyperiid amphipods and salps}

Amphipods as carnivorous organisms (Bowman \& Gruner 1973) depend on the presence of zooplankton prey, particularly gelatinous hosts (Coleman 1994). The occurrence of hyperiid amphipods off Vizcaino Bay and near the coast south of Punta Eugenia in April 2005 appears to be due to abundant salps in these locations (Lavaniegos et al. 2008). These were mixed blooms of Salpa fusiformis and Thalia orientalis. Hyperiid species of the Phronima and Vibilia genera apparently prefer $S$. fusiformis (Table 2). Phronima and Vibilia are large hyperiids and need larger salp species for shelter. Besides the size of the host, the consistency of the gelatinous tissue may be important in the case of Phronima, which live in barrels made of salp tissue. Gelatinous hosts with thicker and denser cuticular layers, such as tunicates of the genera Pyro- 
soma and Salpa as well as large nectophores of the cnidarian Rosacea cymbiformis are preferred by Phronima (Hirose et al. 2005, Lavaniegos 2007). The co-occurrence of Phronima and Salpa spp. in the Georges Bank, Northwest Atlantic is well known (Brown et al. 2005).

The salp species that was most highly correlated with hyperiid species was Cyclosalpa danae (Table 2). The description of this species is relatively recent (van Soest 1975) and there are few geographical records in the literature (Esnal \& Daponte 1999). Interestingly in the present study, C. danae was present only in October when maximal abundances of amphipods were noted. This suggests that $C$. danae might have been an important gelatinous substrate for amphipods in autumn. This might have been the case for Vibilia armata, which was abundant in autumn (Fig. 2) and is known to live in salps. This idea is reinforced by observations (during the laboratory analysis) of small unidentified juvenile hyperiids inside gelatinous tunics in chains of $C$. danae. In contrast to other species, the tunic of Cyclosalpa is weak and has few muscle bands, indicating slow movement; these characteristics make this genus easier to colonize by small hyperiids. Other advantages for hyperiids using aggregates of $C$. danae may be the possibility to remain aggregated for longer periods while occupying the salp tunic in a chain. This was inferred from the observation of long undisrupted chains in the samples despite the stress caused by the sampling tow that could have broken the chain-links apart. Salp aggregates that are joined for a long time in a chain provide a broader host availability and allow amphipod females to successively occupy contiguous aggregates with high survival probability.

The elevated incidence of salp blooms in the Baja California region indicates a high availability of hosts for hyperiids. Many of these erratic occurrences appear to be related to warming events such as El Niños (Hereu et al. 2006). Further work must be done to investigate a possible increase in salps and associated hyperiids, in the context of the global warming. The present study may serve as a baseline for future studies relating hyperiid amphipods to climate variability over longer time scales.

Acknowledgements. We thank the students and the crew of the RV 'Francisco de Ulloa' who worked on the IMECOCAL cruises. J. L. Cadena was in charge of the fieldwork and helped with the counting of major taxa. P. García-García assisted in the taxonomic analysis of salps. This research was supported by the Consejo Nacional de Ciencia y Tecnología (CONACYT) (Grants 47044 and 42569), Secretaría del Medio Ambiente y Recursos Naturales, CONACYT 23804, and the University of California Institute for Mexico and the United States (UC-MEXUS) CN07-125.

\section{LITERATURE CITED}

Aristegui J, Montero MF (2005) Temporal and spatial changes in plankton respiration and biomass in the Canary Islands region: the effect of mesoscale variability. J Mar Syst 54: 65-82

> Barth JA, Pierce SD, Cowles TJ (2005) Mesoscale structure and its seasonal evolution in the northern California Current System. Deep Sea Res II 52:5-28

Batten SD, Crawford WR (2005) The influence of coastal origin eddies on oceanic plankton distributions in the eastern Gulf of Alaska. Deep Sea Res II 52:991-1009

Bowman TE, Gruner HE (1973) The families and genera of Hyperiidea (Crustacea: Amphipoda). Smithson Contrib Zool 146:1-64

> Bradford JM, Chapman BE (1988) Epipelagic zooplankton assemblages and a warm-core eddy off East Cape, New Zealand. J Plankton Res 10:601-619

Brodeur RD, Lorz HV, Pearcy WG (1987) Food habits and dietary variability of pelagic nekton off Oregon and Washington, 1979-1984. NOAA Tech Rep NMFS 57, p 32

Brown H, Bollens SM, Madin LP, Horgan EF (2005) Effects of warm water intrusions on populations of macrozooplankton on Georges Bank, Northwest Atlantic. Cont Shelf Res 25:143-156

Clarke KR, Gorley RN (2006) PRIMER v6: user manual/tutorial. Plymouth routines in multivariate ecological research. PRIMER-E, Plymouth

Coleman CO (1994) Comparative anatomy of the alimentary canal of hyperiid amphipods. J Crustac Biol 14:346-370

Dehn LA, Sheffield GG, Follmann EH, Duffy LK, Thomas DL, O'Hara TM (2007) Feeding ecology of phocid seals and some walrus in the Alaskan and Canadian Arctic as determined by stomach contents and stable isotope analysis. Polar Biol 30:167-181

Esnal GB, Daponte MC (1999) Salpida. In: Boltovskoy D (ed) South Atlantic zooplankton. Backhuys Publishers, Leiden, p 1423-1444

Gasca R (2003) Hyperiid amphipods (Crustacea: Peracarida) in relation to a cold-core ring in the Gulf of Mexico. Hydrobiologia 510:115-124

Gasca R (2004) Distribution and abundance of hyperiid amphipods in relation to summer mesoscale features in the southern Gulf of Mexico. J Plankton Res 26:993-1003

> Gasca R, Franco-Gordo C (2008) Hyperiid amphipods (Peracarida) from Banderas Bay, Mexican tropical Pacific. Crustaceana 81:563-575

> Gasca R, Suárez-Morales E, Haddock SHD (2007) Symbiotic associations between crustaceans and gelatinous zooplankton in deep and surface waters off California. Mar Biol 151:233-242

Gaxiola-Castro G, Durazo R, Lavaniegos BE, De la CruzOrozco ME, Millán-Núñez E, Soto-Mardones L, CepedaMorales J (2008) Pelagic ecosystem response to interannual variability off Baja California. Cienc Mar 34: 263-270

Godeaux JEA (1998) The relationships and systematics of the Thaliacea, with keys for identification. In: Bone Q (ed) The biology of pelagic tunicates. Oxford University Press, Oxford, p 273-294

Goericke R, Venrick E, Mantyla A, Hooff R and others (2005) The state of the California Current, 2004-2005: still cool? Calif Coop Oceanic Fish Invest Rep 46:32-71

Haury LR, Venrick EL, Fey CL, McGowan JA, Niiler PP (1993) The Ensenada Front: July 1985. Calif Coop Oceanic Fish Invest Rep 34:69-88

Henson SA, Thomas AC (2007) Phytoplankton scales of vari- 
ability in the California Current System: 1. Interannual and cross-shelf variability. J Geophys Res 112(C7):C07017

- Hereu CM, Lavaniegos BE, Gaxiola-Castro G, Ohman MD (2006) Composition and potential grazing impact of salp assemblages off Baja California during the 1997-1999 El Niño and La Niña. Mar Ecol Prog Ser 318:123-140

Hereu CM, Lavaniegos BE, Goericke R (in press) Grazing impact of salp (Tunicata, Thaliacea) assemblages in the eastern tropical North Pacific. J Plankton Res

Hirose E, Aoki MN, Nishikawa A (2005) Still alive? Fine structure of the barrels made by Phronima (Crustacea: Amphipoda). J Mar Biol Assoc UK 85:1435-1439

Hormazabal S, Núñez S, Arcos D, Espindola F, Yuras G (2004) Mesoscale eddies and pelagic fishery off central Chile $\left(33-40^{\circ} \mathrm{S}\right)$. Gayana 68:291-296

> Hurlbert SH (1971) The nonconcept of species diversity: a critique and alternative parameters. Ecology 52:577-586

Kosenok NS, Chuchukalo VI, Savinykh VF (2006) The characteristics of feeding of Diaphus theta (Myctophidae) in the northwestern part of the Pacific Ocean in the summerautumn period. J Ichthyol 46:606-612

Lavaniegos BE (2007) Hyperiidea. In: Carlton JT (ed) The Light and Smith manual: intertidal invertebrates from central California to Oregon, 4th edn. University of California Press, Berkeley, p 630

Lavaniegos BE (in press) Influence of a multiyear event of low salinity on the zooplankton from Mexican eco-regions of the California Current. Prog Oceanogr doi:10.1016/j. pocean.2009.07.037

Lavaniegos BE, Ohman MD (1999) Hyperiid amphipods as indicators of climate change in the California Current. In: Schram FR, von Vaupel-Klein JC (eds) Crustaceans and the biodiversity crisis. Proc 4th Int Crustacean Congress, Vol I. Brill, Leiden, p 489-509

Lavaniegos BE, Ohman MD (2003) Long-term changes in pelagic tunicates of the California Current. Deep Sea Res II 50:2473-2498

Lavaniegos BE, Cadena-Ramírez JL, García-García P (2008) Zooplankton biomass and structure off the western coast of Baja California during 2005 (IMECOCAL cruises 0501, 0504, 0507, 0510). Department of Biological Oceanography, CICESE, Tech Rep No. 79123

Logerwell EA, Lavaniegos BE, Smith PE (2001) Spatiallyexplicit bioenergetics of Pacific sardine in the Southern California Bight: Are mesoscale eddies areas of exceptional prerecruit production? Prog Oceanogr 49:391-406

Lorz HV, Pearcy WG (1975) Distribution of hyperiid amphipods off the Oregon coast. J Fish Res Board Can 32: 1442-1447

Mackas DL, Tsurumi M, Galbraith MD, Yelland DR (2005) Zooplankton distribution and dynamics in a North Pacific eddy of coastal origin: II. Mechanisms of eddy colonization by and retention of offshore species. Deep Sea Res II 52: 1011-1035

Mackas DL, Peterson WT, Ohman MD, Lavaniegos BE (2006) Zooplankton anomalies in the California Current system before and during the warm ocean conditions of 2005 . Geophys Res Lett 33:L22S07 doi:10.1029/2006GL027930

Ogi H, Tanaka H, Tsujita T (1985) The distribution and feeding ecology of murres in the northwestern Bering Sea. J Yamashina Inst Ornithol 17:44-56

Peterson WT, Emmett R, Goericke R, Venrick E and others (2006) The state of the California Current, 2005-2006: warm in the north, cold in the south. Calif Coop Ocean Fish Investig Rep 47:30-74
Prasanna-Kumar S, Nuncio M, Narvekar J, Kumar A and others (2004) Are eddies nature's trigger to enhance biological productivity in the Bay of Bengal? Geophys Res Lett 31:L07309. doi:10.1029/2003GL019274

Repelin R (1978) Les amphipodes pélagiques du Pacifique occidental et central. Biologie, écologie et relations trophiques avec la faune ichthyologique. Trav Doc ORSTOM 86:1-381

Schabetsberger R, Morgan CA, Brodeur RD, Potts CL, Peterson WT, Emmett RL (2003) Prey selectivity and diel feeding chronology of juvenile chinook (Oncorhynchus tshawytscha) and coho (O. kisutch) salmon in the Columbia River plume. Fish Oceanogr 12:523-540

> Schwing FB, Bond NA, Bograd SJ, Mitchell T, Alexander MA, Mantua N (2006) Delayed coastal upwelling along the U.S. West Coast in 2005: a historical perspective. Geophys Res Lett 33: L22S01, doi:10.1029/2006GL026911

Shulenberger E (1977) Hyperiid amphipods from the zooplankton community of the North Pacific central gyre. Mar Biol 42:375-385

> Shulenberger E (1982) Biological evidence for a split in the North Pacific central gyre. Deep Sea Res A 29:403-410

Siegel-Causey D (1982) Factors determining the distribution of hyperiid Amphipoda in the Gulf of California. PhD thesis, University of Arizona, Tucson

Soto-Mardones L, Parés-Sierra A, García J, Durazo R, Hormazabal S (2004) Analysis of the mesoscale structure in the IMECOCAL region (off Baja California) from hydrographic, ADCP and altimetry data. Deep Sea Res II 51: 785-798

Suntsov AV, Brodeur RD (2008) Trophic ecology of three dominant myctophid species in the northern California Current region. Mar Ecol Prog Ser 373:81-96

Sydeman WJ, Bradley RW, Warzybok P, Abraham CL and others (2006) Planktivorous auklet Ptychoramphus aleuticus responses to ocean climate, 2005: unusual atmospheric blocking? Geophys Res Lett 33:L22S09, doi:10.1029/ 2006GL026736

Uchikawa K, Bower JR, Sato Y, Sakurai Y (2004) Diet of the minimal armhook squid (Berryteuthis anonychus) (Cephalopoda: Gonatidae) in the northeast Pacific during spring. Fish Bull (Wash D C) 102:733-739

van Soest RMW (1972) The genus Thalia Blumenbach, 1798 (Tunicata, Thaliacea), with descriptions of two new species. Beaufortia 20:193-212

van Soest RMW (1975) Zoogeography and speciation in the Salpidae (Tunicata: Thaliacea). Beaufortia 23:181-215

> Venrick EL (2000) Summer in the Ensenada Front: the distribution of phytoplankton species, July 1985 and September 1988. J Plankton Res 22:813-841

Vinogradov GM (1991) Hyperiid amphipods in the eastern part of the South Pacific gyre. Mar Biol 109:259-265

Vinogradov ME, Volkov AF, Semenova TN (1996) Hyperiid amphipods of the world oceans. Science Publishers, New Delhi

Watanabe H, Kubodera T, Kawahara S (2003) Feeding habits of Pacific pomfret Brama japonica in the transition zone of the central North Pacific. Fish Sci 69:269-276

Young JW, Anderson DT (1987) Hyperiid amphipods (Crustacea: Peracarida) from a warm-core eddy in the Tasman Sea. Aust J Mar Freshw Res 38:711-725

> Young JW, Lamb TD, Le D, Bradford RW, Whitelaw AW (1997) Feeding ecology and interannual variations in diet of southern bluefin tuna, Thunnus maccoyii, in relation to coastal and oceanic waters off eastern Tasmania, Australia. Environ Biol Fishes 50:275-291 
Appendix 1. Hyperiid amphipod species observed during the 4 seasons in 2005. Geometric mean (GM) and number of samples (NS) with positive records are shown. Abundance data (ind. $1000 \mathrm{~m}^{-3}$ ) were log transformed $\left(\log _{10}[x+1]\right)$ prior to calculation of the mean, and then back-transformed to obtain the geometric mean. The total number of samples analyzed is shown in parentheses. (+) Abundance $<0.1$ ind. $1000 \mathrm{~m}^{-3},(-)$ absent, (?) uncertain whether this is the correct species

\begin{tabular}{|c|c|c|c|c|c|c|c|c|}
\hline \multirow[t]{2}{*}{ Species } & \multicolumn{2}{|c|}{ January (52) } & \multicolumn{2}{|c|}{ April (39) } & \multicolumn{2}{|c|}{ July (41) } & \multicolumn{2}{|c|}{ October (41) } \\
\hline & GM & NS & GM & NS & GM & NS & GM & NS \\
\hline \multicolumn{9}{|l|}{ Infraorder Physosomata } \\
\hline \multicolumn{9}{|l|}{ Family Lanceolidae } \\
\hline Lanceola clausi & - & 0 & + & 1 & - & 0 & - & 0 \\
\hline Scypholanceola aestiva & - & 0 & - & 0 & + & 1 & - & 0 \\
\hline Scypholanceola agassizi & - & 0 & - & 0 & + & 2 & - & 0 \\
\hline \multicolumn{9}{|l|}{ Family Scinidae } \\
\hline Acanthoscina acanthodes & - & 0 & - & 0 & - & 0 & + & 1 \\
\hline Acanthoscina birsteini & - & 0 & + & 1 & - & 0 & - & 0 \\
\hline Scina borealis & 0.8 & 19 & 1.8 & 24 & 0.9 & 15 & 0.9 & 15 \\
\hline Scina curvidactyla & + & 1 & - & 0 & 0.1 & 2 & + & 1 \\
\hline Scina excisa & + & 2 & + & 1 & - & 0 & - & 0 \\
\hline Scina similis & + & 1 & - & 0 & - & 0 & - & 0 \\
\hline Scina stebbingi? & - & 0 & - & 0 & - & 0 & + & 1 \\
\hline Scina stenopus & + & 2 & 0.1 & 3 & 0.1 & 4 & 0.1 & 3 \\
\hline Scina tullbergi & 0.3 & 10 & 3.4 & 28 & 5.3 & 32 & 5.1 & 35 \\
\hline Scina wolterecki & - & 0 & - & 0 & + & 1 & - & 0 \\
\hline \multicolumn{9}{|l|}{ Infraorder Physocephalata } \\
\hline \multicolumn{9}{|l|}{ Family Vibilidae } \\
\hline Vibilia armata & 8.3 & 37 & 25.5 & 34 & 34.5 & 35 & 29.3 & 36 \\
\hline Vibilia australis & 0.2 & 8 & 0.8 & 13 & 1.7 & 22 & 0.6 & 12 \\
\hline Vibilia caeca & + & 1 & - & 0 & + & 1 & - & 0 \\
\hline Vibilia chuni & + & 1 & 0.1 & 3 & 0.1 & 4 & 0.4 & 8 \\
\hline Vibilia cultripes & 0.1 & 3 & - & 0 & 0.1 & 2 & + & 1 \\
\hline Vibilia gibbosa & 0.4 & 11 & 1.8 & 17 & + & 1 & 0.4 & 10 \\
\hline Vibilia longicarpus & - & 0 & - & 0 & + & 1 & - & 0 \\
\hline Vibilia propinqua & 0.1 & 3 & - & 0 & + & 1 & + & 1 \\
\hline Vibilia pyripes & - & 0 & + & 1 & 0.1 & 3 & + & 1 \\
\hline Vibilia robusta & 0.1 & 3 & 0.1 & 2 & + & 2 & + & 1 \\
\hline Vibilia stebbingi & 0.1 & 5 & + & 1 & 0.2 & 4 & 0.7 & 11 \\
\hline Vibilia viatrix & 1.5 & 29 & 5.4 & 30 & 0.6 & 15 & 0.7 & 15 \\
\hline Family Paraphronimidae & & & & & & & & \\
\hline Paraphronima crassipes & 0.2 & 6 & 0.3 & 6 & 0.8 & 17 & 1.6 & 23 \\
\hline Paraphronima gracilis & 1.5 & 26 & 3.4 & 27 & 3.6 & 28 & 9.1 & 34 \\
\hline Family Phronimidae & & & & & & & & \\
\hline Phronima atlantica & 2.0 & 31 & 1.9 & 22 & 1.3 & 22 & 0.6 & 14 \\
\hline Phronima bucephala & - & 0 & + & 1 & + & 1 & + & 1 \\
\hline Phronima colleti & 0.1 & 2 & - & 0 & + & 1 & - & 0 \\
\hline Phronima curvipes & 1.9 & 28 & 1.3 & 16 & 0.8 & 17 & 0.6 & 10 \\
\hline Phronima pacifica & 0.2 & 8 & 0.4 & 7 & 0.2 & 4 & 0.1 & 3 \\
\hline Phronima sedentaria & 1.2 & 26 & 1.2 & 18 & 0.6 & 14 & 0.3 & 9 \\
\hline Phronima solitaria & 0.1 & 2 & + & 1 & + & 1 & 0.1 & 2 \\
\hline Phronima stebbingi & 0.7 & 17 & 0.4 & 8 & 0.5 & 12 & 0.2 & 7 \\
\hline Phronimella elongata & 0.3 & 10 & 0.3 & 7 & + & 1 & 0.4 & 8 \\
\hline Family Phrosinidae & & & & & & & & \\
\hline Anchylomera blossevillei & 3.7 & 35 & 2.7 & 23 & 1.0 & 16 & 1.1 & 16 \\
\hline Phrosina semilunata & 1.0 & 24 & 2.9 & 24 & 2.2 & 22 & 1.2 & 20 \\
\hline Primno brevidens & 3.6 & 32 & 11.1 & 32 & 19.1 & 37 & 40.2 & 37 \\
\hline Primno latreillei & - & 0 & - & 0 & - & 0 & + & 1 \\
\hline Family Hyperiidae & & & & & & & & \\
\hline Hyperoche capucinus? & - & 0 & - & 0 & 0.1 & 1 & - & 0 \\
\hline Hyperoche cryptodactylus & + & 1 & 0.1 & 3 & 0.2 & 4 & 0.1 & 4 \\
\hline Hyperoche mediterranea & - & 0 & - & 0 & + & 1 & 0.1 & 2 \\
\hline Hyperoche medusarum & 0.3 & 8 & 2.0 & 20 & 2.9 & 24 & 1.9 & 20 \\
\hline Hyperoche picta & - & 0 & 0.1 & 2 & + & 1 & - & 0 \\
\hline Laxohyperia vespuliformis & 0.2 & 8 & 1.2 & 17 & 1.2 & 20 & 3.8 & 32 \\
\hline Themisto pacifica? & + & 2 & + & 1 & - & 0 & - & 0 \\
\hline Family Lestrigonidae & & & & & & & & \\
\hline Hyperietta luzoni & - & 0 & - & 0 & 0.1 & 3 & - & 0 \\
\hline Hyperietta parviceps & 0.6 & 14 & 2.3 & 20 & 0.9 & 15 & 8.0 & 33 \\
\hline Hyperietta stebbingi & 0.2 & 6 & 0.8 & 12 & 0.5 & 11 & 1.6 & 20 \\
\hline Hyperietta stephenseni & 0.3 & 8 & 1.1 & 15 & 0.5 & 10 & 1.5 & 21 \\
\hline Hyperietta vosseleri & 0.3 & 8 & 0.3 & 8 & 0.2 & 6 & 2.8 & 23 \\
\hline Hyperioides sibaginis & 0.2 & 8 & + & 1 & 0.8 & 9 & 0.4 & 4 \\
\hline Hyperioides longipes & 0.5 & 10 & 1.2 & 18 & - & 0 & 2.1 & 22 \\
\hline Lestrigonus bengalensis & 0.7 & 17 & 4.6 & 26 & 2.9 & 22 & 40.7 & 39 \\
\hline Lestrigonus macrophthalmus & + & 1 & 0.1 & 1 & 0.1 & 1 & 0.5 & 13 \\
\hline Lestrigonus schizogeneios & 0.5 & 11 & 10.8 & 33 & 5.1 & 23 & 72.5 & 40 \\
\hline Lestrigonus shoemakeri & 0.1 & 4 & 3.3 & 23 & 2.6 & 21 & 5.7 & 34 \\
\hline
\end{tabular}


Appendix 1 (continued)

\begin{tabular}{|c|c|c|c|c|c|c|c|c|}
\hline \multirow{2}{*}{ Species } & \multicolumn{2}{|c|}{ January (52) } & \multicolumn{2}{|c|}{ April (39) } & \multicolumn{2}{|c|}{ July (41) } & \multicolumn{2}{|c|}{ October (41) } \\
\hline & GM & NS & GM & NS & GM & NS & GM & NS \\
\hline Phronimopsis spinifera & 1.9 & 20 & 2.2 & 22 & 0.5 & 11 & 0.2 & 7 \\
\hline Themistella fusca & 0.1 & 4 & 0.1 & 2 & - & 0 & 5.3 & 27 \\
\hline \multicolumn{9}{|l|}{ Family Iulopidae } \\
\hline Iulopis mirabilis & + & 1 & 0.3 & 7 & - & 0 & - & 0 \\
\hline \multicolumn{9}{|l|}{ Family Dairellidae } \\
\hline Dairella californica & 0.1 & 2 & 0.1 & 4 & - & 0 & 0.1 & 2 \\
\hline \multicolumn{9}{|l|}{ Family Lycaeopsidae } \\
\hline Lycaeopsis themistoides & 0.6 & 15 & 1.1 & 16 & 0.9 & 15 & 1.6 & 21 \\
\hline Lycaeopsis zamboangae & 0.1 & 4 & 0.2 & 5 & 0.1 & 3 & 1.6 & 18 \\
\hline \multicolumn{9}{|l|}{ Family Pronoidae } \\
\hline Eupronoe armata & + & 1 & 0.3 & 7 & 0.1 & 3 & 0.3 & 8 \\
\hline Eupronoe maculata & 0.1 & 4 & 0.1 & 3 & 0.1 & 2 & 1.4 & 14 \\
\hline Eupronoe minuta & 7.6 & 43 & 14 & 33 & 22.5 & 35 & 21.0 & 37 \\
\hline Paralycaea gracilis & 0.1 & 2 & - & 0 & + & 1 & - & 0 \\
\hline Parapronoe campbelli & - & 0 & 0.2 & 4 & 0.1 & 4 & - & 0 \\
\hline Parapronoe crustulum & 0.2 & 6 & 0.2 & 4 & 0.3 & 7 & 0.1 & 3 \\
\hline Parapronoe elongata & 0.1 & 2 & - & 0 & - & 0 & - & 0 \\
\hline Parapronoe parva & 0.1 & 4 & 0.4 & 9 & 0.2 & 6 & 0.7 & 14 \\
\hline Pronoe capito & 0.1 & 6 & 0.2 & 5 & 0.3 & 9 & 0.2 & 6 \\
\hline \multicolumn{9}{|l|}{ Family Anapronoidae } \\
\hline Anapronoe reinhardti & - & 0 & - & 0 & 0.1 & 2 & - & 0 \\
\hline Family Lycaeidae & & & & & & & & \\
\hline Lycaea lilia & + & 2 & - & 0 & 0.1 & 1 & - & 0 \\
\hline Lycaea nasuta & - & 0 & - & 0 & 0.1 & 1 & - & 0 \\
\hline Lycaea pachypoda & 0.2 & 6 & 0.8 & 11 & 0.1 & 2 & 0.1 & 2 \\
\hline Lycaea pauli & - & 0 & - & 0 & 0.1 & 1 & - & 0 \\
\hline Lycaea pulex & 0.2 & 7 & 0.3 & 6 & 0.1 & 4 & 3.2 & 21 \\
\hline Lycaea serrata & 0.1 & 3 & 0.2 & 6 & 0.3 & 6 & 0.2 & 3 \\
\hline Simorhynchotus antennarius & 0.9 & 19 & 1.5 & 17 & 2.1 & 21 & 13.1 & 35 \\
\hline Family Tryphaneidae & & & & & & & & \\
\hline Tryphana malmi & 0.1 & 4 & 0.2 & 4 & 0.6 & 11 & 0.5 & 12 \\
\hline Family Brachyscelidae & & & & & & & & \\
\hline Brachyscelus crusculum & 0.1 & 3 & 0.2 & 5 & 0.1 & 4 & 0.4 & 9 \\
\hline Brachyscelus globiceps & 0.1 & 3 & 0.1 & 3 & 0.5 & 7 & 0.9 & 11 \\
\hline Euthamneus rostratus & - & 0 & - & 0 & 0.1 & 3 & - & 0 \\
\hline Family Oxycephalidae & & & & & & & & \\
\hline Calamorhynchus pellucidus & 0.2 & 7 & 0.2 & 5 & 0.3 & 10 & 0.2 & 7 \\
\hline Cranocephalus scleroticus & + & 2 & - & 0 & - & 0 & 0.1 & 3 \\
\hline Glossocephalus milneedwardsi & 0.1 & 4 & 0.2 & 5 & 0.3 & 6 & 0.3 & 8 \\
\hline Oxycephalus clausi & 0.5 & 13 & 0.6 & 11 & 0.3 & 7 & 1.4 & 19 \\
\hline Oxycephalus latirostris & - & 0 & - & 0 & 0.1 & 2 & - & 0 \\
\hline Oxycephalus longipes & - & 0 & - & 0 & + & 1 & - & 0 \\
\hline Oxycephalus piscator & 0.1 & 5 & 0.2 & 6 & 0.2 & 3 & 0.1 & 3 \\
\hline Rhabdosoma armatum & - & 0 & + & 1 & + & 1 & - & 0 \\
\hline Rhabdosoma brevicaudatum & 0.1 & 3 & - & 0 & - & 0 & - & 0 \\
\hline Rhabdosoma minor & + & 1 & - & 0 & - & 0 & 0.1 & 3 \\
\hline Rhabdosoma whitei & 1.0 & 20 & 0.5 & 12 & 0.4 & 11 & 0.7 & 16 \\
\hline Streetsia challengeri & 0.4 & 12 & 1.4 & 21 & 1.3 & 21 & 0.9 & 18 \\
\hline Streetsia mindanaonis & + & 2 & - & 0 & - & 0 & - & 0 \\
\hline Streetsia porcella & + & 2 & - & 0 & - & 0 & 0.1 & 2 \\
\hline Streetsia steenstrupi & 0.4 & 14 & 0.6 & 13 & 0.5 & 11 & 0.4 & 9 \\
\hline Tullbergella cuspidata & + & 1 & - & 0 & - & 0 & + & 1 \\
\hline Family Platyscelidae & & & & & & & & \\
\hline Amphithyrus bispinosus & 0.1 & 4 & 0.1 & 2 & 0.1 & 3 & - & 0 \\
\hline Amphithyrus sculpturatus & 0.2 & 7 & 0.3 & 6 & 0.3 & 5 & 0.9 & 15 \\
\hline Hemityphis tenuimanus & + & 2 & + & 1 & - & 0 & 0.2 & 4 \\
\hline Paratyphis maculatus & - & 0 & - & 0 & + & 1 & - & 0 \\
\hline Paratyphis promontori & - & 0 & + & 1 & + & 1 & - & 0 \\
\hline Paratyphis spinosus & + & 1 & - & 0 & - & 0 & - & 0 \\
\hline Platyscelus ovoides & 1.3 & 24 & 1.2 & 14 & 1.3 & 16 & 0.8 & 12 \\
\hline Platyscelus serratulus & 0.7 & 16 & 0.6 & 12 & 0.4 & 7 & 2.7 & 26 \\
\hline Tetrathyrus forcipatus & + & 1 & - & 0 & - & 0 & 0.1 & 2 \\
\hline Family Parascelidae & & & & & & & & \\
\hline Hemiscelus diplochelatus? & - & 0 & - & 0 & + & 1 & - & 0 \\
\hline Parascelus edwardsi & 0.3 & 10 & 0.7 & 13 & 0.1 & 2 & 0.6 & 13 \\
\hline Parascelus typhoides & 0.1 & 4 & 0.6 & 11 & 0.3 & 7 & 0.4 & 10 \\
\hline Schizoscelus ornatus? & - & 0 & - & 0 & + & 1 & - & 0 \\
\hline Thyropus sphaeroma & + & 1 & 0.1 & 2 & - & 0 & + & 1 \\
\hline
\end{tabular}

